\title{
Leadership Type: Sutomo Strategic Leadership at the Battle of Surabaya November 10, 1945
}

\author{
Albert Agung Wijaya, Priyanto, Wayan Nurida \\ Prodi Strategi Perang Semesta, Fakultas Strategi Pertahanan, Universitas Pertahanan, Indonesia
}

\begin{abstract}
In the battle of Surabaya 1945 there was a figure who was able to burn the spirit of the people of Surabaya to dare to die against the invaders, the figure is Sutomo or better known as Sutomo, therefore the author is interested in reviewing and analyzing the Background of the Battle of November 10, 1945 in Surabaya and Reviewing the Role of Sutomo Strategic Leadership in the Battle. This paneling method uses qualitative descriptive methods. According to Sugiyon, descriptive methods are studies that describe, describe, or describe the state of the object studied as what it is, according to the situation and conditions when the research is done. The study also uses a qualitative approach. Sutomo at all times galvanized and stimulated the revolutionary spirit organized into one giant fortress to face the Allies (Britain). Sutomo's fiery voice shrilled the enemy's guts we will not stop the fighting as long as the Dutch army is still on the Indonesian mainland. This voice indirectly weakens the spirit of the enemy who already feels anxious to face the fierce resistance of the Indonesian nation. In leadership has implemented strategic leadership, as well as has a bureaucratic leadership style, charismatic leadership style, analistic leadership style and visionary leadership style. Sutomo strategic leadership can be used as an example for Indonesian citizens, especially for youth to model their strategic leadership, namely in terms of decision making needed to think critically and think analytically, in order to predict the future impact of the decisions taken.
\end{abstract}

Keywords: Leadership, Surabaya, Sutomo, War, Strategic.

\section{INTRODUCTION}

$\mathrm{S}$ urabaya is included in the territory of West Indonesia precisely in the region of East Java. Based on historical research, it shows that Surabaya developed from the village of Ujung Galuh located in the mouth of Kali Surabaya, which joined pacekan village, which is located in the present municipal area. Galuh end is also called Sugalu or Suyalu, but the name of Curabhaya Village is already in the inscription Trowulan I (1358 AD), even though the place already existed before[1]. The victory of Allied forces in World War II against its enemies Germany, Italy and Japan had a major impact on the colonies of Germany, Italy, and Japan including Indonesia which is a Japanese colony. This provided an opportunity for the allied countries to re-establish their power against the colonial state that had been seized by the Fascist state. This opportunity was utilized by the Dutch to re-colonize Indonesia or the Dutch East Indies terms preferred by the Dutch. Countries that lose wars are obliged to maintain the "status quo" of their colonies. This also applies to Indonesia which is a Japanese-occupied territory[2].

News of Japan's surrender to the Allies temporarily became a secret because people were afraid to talk about it openly to make the situation in society even more tense. This tension lasted until on August 17, 1945 the proclamation of Indonesian independence was read by President Sukarno in Jakarta. News about the proclamation of Indonesian independence can penetrate Surabaya the state of surabaya city is still covered by tensions[4]. The proclamation of Indonesian independence has a big impact on the people of Indonesia, Indonesia is independent with the raising of the Red and White flag in various regions including in Surabaya. This was a blatant violation of the "status quo" that had to be maintained and maintained by the Japanese army that had become a tool of the Allied army. So no wonder there are often incidents or bloody clashes between Japanese soldiers who must maintain the "status quo" with surabaya arek-arek. The condition of Arekarek Surabaya at that time could be filled with bonek "bondo desperate" because it began desperate to carry out siege and raid on the Japanese headquarters[5]. In the battle of Surabaya 1945 there was a figure who was able to burn the spirit of the people of Surabaya to dare to die against the invaders, the figure is Sutomo or better known as Sutomo. In Sutomo speeches often say Allahu Akbar (Allah is great). Sutomo is known as the leader of barisan Barisan Rakyat Indonesia (BPRI) who always speaks on the rebellion radio to burn the spirit of resistance of surabaya people's fighters. Sutomo at all times galvanized and stimulated the revolutionary spirit organized into one giant fortress to face the Allies (Britain). Sutomo's fiery voice shrilled at the enemy's guts with cries of we will not stop fighting as long as the Dutch army (foreign troops) are still on the Indonesian mainland[6]. The event made Sutomo close to the people and became popular. Sutomo has a different way of the struggle to maintain independence in Surabaya, namely by inflame the spirit of the people through radio, which is why the author is interested in reviewing and analyzing the Background of the Battle of November 10, 1945 in Surabaya and Reviewing the Role of Sutomo Strategic Leadership in the Battle.

\section{RESEARCH METHODS}

This paneling method uses qualitative descriptive methods. According to Sugiyono[7], descriptive methods are studies that describe, describe, or describe the state of the object studied as what it is, in accordance with the situation and conditions when the research is carried out. The study also uses a qualitative approach. According to Sugiyono[7], qualitative approach is a research mechanism of work based on nonstatistic or nonmamatic subjective assessment, where the measure of values used in this study is not score numbers, but 
categorization of values or quality. The reason for using such methods is because qualitative methods aim to describe the actual circumstances or conditions that exist in the field especially in relation to the theme of the research taken.

\section{RESULTS AND DISCUSSIONS}

\subsection{A Background battle of Surabaya November 10, 1945}

After the Proclamation of Independence, the state security situation began to worry. This was due to the entry of allied troops into Indonesia which was occupied by NICA, which was given the task of restoring the civilian and legal government of the Dutch East Indies (Indonesia) colonial government after the defeat of Japanese troops on Indonesian territory after World War II. Of course, the newly independent Indonesian nation has concerns, and feels a threat that can interfere and even undermine independence[8].

The Battle of Surabaya on November 10, 1945 was the battle of the people of Surabaya to reject the arrival of allies who wanted to colonize Indonesia specifically surabaya area. The youth of Surabaya at that time held a fight to defend and defend our Proclamation of Independence, which was announced in Jakarta on August 17, 1945 without thinking about the risks, victims and suffering. All that is thought is how the motto "Once Free, Remain Free" can be implemented. This reflects the soul of "Suro-Hing-Boyo", the original name of the city of Surabaya which means "Brave in Danger"[9].

News of the landing of Allied forces on October 25, 1945 in Surabaya was first reported by Information Minister Amir Syarifudin, from Jakarta. In the news explained the duties of allied forces in Indonesia and advised the local government in Surabaya to accept well allied troops and help the tasks carried out by the allied army. Based on the Allied mission, it is clear that the arrival of the Allies to Indonesia was for good intentions and not to trample on the sovereignty of the Indonesian nation that we have proclaimed on August 17, 1945. To explain the political attitude of the central government, it has also come to Surabaya a delegation from Jakarta led by Mr. Kasman Singodimedjo (Chairman of the Central Indonesian National Committee), Defense Minister Mohammad Suryo Adikusumo and Dr.Kodyat. The political attitude of the central government is difficult to accept by the people of Surabaya in general who suspect the arrival of the Allies to Indonesia is an attempt to help restore Dutch colonialism in Indonesia, this is closely related to the case of Colonel PG. Huijer, a Dutch allied army officer who came to Surabaya for the first time on September 23, 1945, as the envoy of the first Admiral Patterson, the allied leader / navy in Southeast Asia turned out to bring a secret mission also from the supreme leader of the Royal Dutch navy so as to further add to the suspicions of the Indonesian people in Surabaya. Huijer who at that time openly opposed the Indonesian revolution, so finally arrested and taken prisoner by the Indonesian security forces. However, when allied forces landed in Surabaya on October 25, 1945, the Indonesian people in Surabaya received it with open arms and peacefully[9].
Since a month of reading the proclamation text, a RAPWI (Rehabilitaion of Allied Prisoners of War and Internees) organization has been established in charge of prisoners and internments. The establishment of RAPWI has a veiled intention, namely preparing for the arrival of allies who want to land in Surabaya. RAPWI is headquartered in Hotel Yamato which is inhabited by the remains of Dutch internment. On 18 September, two Dutch nationals named Ploegman and Spit who were members of the Social Contact Committee raised the Dutch tricolor flag (Rood - Wit - Blauw) at the Yamato Hotel[10]. Quickly the news of the incident spread and angered the youth of Surabaya. The next day on September 19, people started swarming the Yamato Hotel. Many of them carry sharp weapons such as spears, kris, pointed bamboo, machetes and other weapons demanded that the Dutch flag be taken down. The Dutch officer who was inside the hotel seemed reluctant to comply with the demands so there was an incident between the two sides. The event ended with the tearing of blue cloth on the Dutch tricolor flag and was raised back to red and white. After the flag tear at the Yamato Hotel, there was also the arrest of Colonel P.J.G. Huijer.

Huijer's existence in Indonesia was a form of Dutch concern about the strength of the Republics who at that time were actively strengthening their military. That's why Huijer was sent to review the situation in Surabaya. Moreover, Surabaya is a strategic maritime city. Huijer, who had previously arrived in Surabaya on September 23, was found to have opposed the independence revolution at the behest of the supreme leadership of the Royal Dutch Navy. Huijer was later arrested by surabaya authorities and thrown into Kalisosok prison[11].

On October 25, an allied army entourage represented by the British on behalf of AFNEI came to Surabaya. The allied landings in Surabaya were led directly by Brigadier General A.W. S. Mallaby with the intention of disarming the Japanese soldiers still in Surabaya and transporting prisoners of war held captive during the previous Japanese occupation. Amir Syariffudin who was then the minister of information had informed the Surabaya Karesidenan government to welcome the intention of the arrival of the ally. But the people of Surabaya are suspicious of the arrival of the British, especially Sutomo. Sutomo speculated that the arrival of the British had its own purpose, which was to help the Dutch restore their colonization in Indonesia. Sutomo then invited the people of Surabaya to be wary of the arrival of the British. The speculation arose on the basis of the Yamato Hotel incident and Huijer's arrest that had occurred before. On the basis of this speculation Sutomo was worried about the return of the Dutch occupation of Indonesia. With his experience as a journalist, Sutomo began to try to take action to prevent it. Sutomo then proposed to Amir Syariffudin to maintain the spirit of the people by broadcasting it on the radio and inviting the people to always be vigilant, but the proposal was rejected. Amir Syarifuddin thinks it will actually aggravate the situation. However, Amir did not object and even suggested that a radio transmitter be formed that could be used as a republic propoganda in addition to official government radio (RRI).[12] 
Amir also appointed to make a simple transmitter radio that can be used by Sutomo, but for a while Sutomo can use the transmitter owned by RRI Surabaya. In addition to using radio as a medium to keep burning the spirit of the people, Sutomo also took the initiative to form an independent nongovernmental body whose purpose is to accommodate the fighting spirit of the people. On October 12, 1945, the Indonesian People's Rebellion Line (BPRI) was formed at Jl. Biliton No. 7 Surabaya with Sutomo itself at the helm. BPRI declared itself as an extremist line aimed at dispelling anyone who interferes with the sovereignty of the Republic of Indonesia. BPRI gathered its members by containing people from the commoners such as rickshaw drivers, coachmen, food invaders, to village youth who dared to die[12]

News of the arrival of President Sukarno and his entourage was broadcast by the rebellion radio[9]. The results of the negotiations between Sukarno and Brigadier General Mallaby have been announced, but not all the people of Surabaya heard and knew the results of President Sukarno's negotiations with Brigadier General Mallaby this was due to the difficulty of communication tools. As around the Lindeteves Building near the Ant Bridge and the Internatio Building near the Red Bridge, things have not subsided[13]. Suddenly the Allied (British) soldiers who were in the building opened fire on the people and youth scattered in the Triangular field in front of the Internatio Building and to the Bureau Contact cars. The shots of the Allied (British) soldiers were then countered by the young men who were outside the building. The unexpected attack has caused so many casualties among the mass of youths around the Internatio Building. Suddenly the car driven by Brigadier General Mallaby was hit by gunfire then exploded and caught fire, It is not known who opened fire on the car whether from the Allied (British) side itself or from the Indonesian side. British army chief Brigadier General Mallaby was killed. Brigadier General Mallaby's death has attracted mixed reactions and comments from various world newspapers. With headlines of the incident published in newspapers including in London, New York, Washington, Australia, and India whose sources were one-sided, namely British sources[14].

On November 10, 1945 at 6:00 a.m. warships from The 5th Cruiser Squadron led by Real Admiral W. R. Petterson aboard the cruiser HMS Sussex as a British-flagged ship anchored in front of the coast of Surabaya began firing its cannons simultaneously into the center of Surabaya. General Mansergh has kept his promise, the ultimatum is in effect, the enemy has started to attack, since then every armed man in Surabaya has been free from the prohibition to fire his weapons towards the enemy that is the pioneer of Dutch colonialization[15].

Fierce fighting raged everywhere around the harbor and by midday the battles were getting more intense and exciting. The People of Indonesia defended their city very hard. That day alone according to Surabaya radio, three British aircraft were killed to earth shot down by our soldiers. General Mansergh then ordered to distribute pamphlets containing demands for surabaya's arek-arek to surrender, stop the fighting and surrender his weapons. It is better to be destroyed than to surrender a voice of the people's rebels from Surabaya radio. Radio Surabaya, called Rebel Radio, broadcast how British warships shelled the city of Surabaya from the port and how its airships and tanks bombed innocent civilians. One-third of Surabaya was destroyed. The Chinese, most of whom were city dwellers, killed men, women, the elderly, young and even children[16].

\subsection{Sutomo Strategic Leadership at the Battle of November 10}

Sutomo was born in Surabaya, precisely in blauran village on October 3, 1920. Sutomo's father named Kartawan Tjiptowidjojo worked as a klerk in the karesidenan office who eventually chose to quit the job and work as a mid-level assistant in the tax office of the praja city government. Sutomo's father is known as a brave man. Genealogically the trait decreases to Sutomo. The brave nature of criticizing firmly is often done Sutomo both to his enemies (in this case the Netherlands) and to friends and the government[4]. During the Indonesian independence revolution, especially in Surabaya, Sutomo fought to become the head of the information section of the Youth of the Republic of Indonesia (PRI), the largest organization in Surabaya at that time. However, Sutomo later resigned from the PRI, establishing BPRI (Barisan Barisan Rakyat Indonesia) with Abdullah, Sumarno, Asmawan and Amiadji[17]. His resignation caused polemics between the bodies of struggle, because it was considered to divide the people. Sutomo's resignation from the PRI was motivated by his visit to Jakarta in early October 1945. Sutomo was very disappointed when he saw the attitude of the Dutch people who did not respect the independence of the Republic of Indonesia. Dutch people marched on the streets of the capital in cars cheering and shouting while waving their national flags, like people who had just won the war. The state of the capital city like that was never imagined in the mind of Sutomo, because the one in Surabaya is very different from what he saw in the capital. The people and youth of Surabaya welcomed the news of the proclamation of independence and made the Japanese army powerless to face the independence of the people of Surabaya who were struggling violently[17].

Sutomo in the battle of November 10, 1945 in Surabaya appeared as one of the young Indonesians who fought against the colonialism of the British army accompanied by NICA. Sutomo has a strategic role as chairman of BPRI which proclaims the spirit of struggle through the Indonesian People's Rebel Radio. Sutomo formed BPRI with the aim that all Indonesians realize that the Allies do not recognize Indonesia as an independent country. Therefore, the people must unite to prevent the return of colony power by the allies. Sutomo managed to raise the spirit of the people to fight against british army troops in Surabaya by speaking through Rebellion Radio. For his background and character formation in his youth, Sutomo has become one of the few agitators this nation has ever had. This incident remains recorded as one of the most important events in Indonesia's history with Sutomo as a successful agitator in indonesia[17]. 
Everyone is born a leader, on a smaller scale he becomes a leader in his personal, while on big things can be a leader in institutions, companies, organizations and so on. Efforts to carry out his leadership then needed things that are used as guidelines, tools, media, means, power, the ability to achieve a goal in his leadership. Managing this is a step in state leadership[18]. In Drukcer's opinion in Moeljono, it states that the leader is the individual human being[19].

Leadership is an inherent trait to him as a leader. To begin this understanding of leaders, we need to pay attention to the understanding of leaders: According to Hersey and Blanchard, "A leader is someone who can influence another person or group to perform the maximum performance that has been established in accordance with the goals of the organization"[20].

Leadership is the art and ability to influence and guide subordinates so that from the led party arises the will, trust, respect and obedience required in the use of tasks carried out to him, using tools and time but contains compatibility between group goals or unity with individual needs or goals[21].

In bridging the understanding of leaders and leaders or leaders and leadership needs to deepen some basic theories between leaders and leadership, through a comparative analysis, namely:

1) Genetic Theory (Heredity): The essence of the theory states that "Leader is born and not made" (the leader is born (talent) instead of made). Adherents of this school of theory express their opinion that a leader will become a leader because he has been born with leadership talent. In circumstances that a person is placed in because he is destined to be a leader, he will occasionally arise as a leader. Speaking of destiny, philosophically this view belongs to the view of facility or determinitis[20].

2) Social Theory: If the first theory above is an extreme theory on the one hand, then it is an extreme on the other. The essence of this school of social theory is that "Leader is made and not born" (the leader is made or educated instead of natural). So this theory is the opposite of the core theory of genetics. The adherents of this theory present the opinion that everyone can be a leader if given enough education and experience.

3) Ecological Theory: The two extreme theories above do not contain all truth, so in reaction to both theories came the third theory. This theory called ecological theory basically means that a person will only succeed in becoming a good leader if he already has leadership talent. Such talents are then developed through regular education and experience that allows it to be further developed. This theory combines the positive aspects of the two earlier theories so that it can be said to be the theory that is closest to truth. However, much more indepth research is still needed to be able to say exactly what factors cause the emergence of a good leader[20].
Strategic leadership consists of a series of two words, namely leadership and strategy. "Leadership is the process of directing, guiding, influencing, controlling one's thoughts, feelings or actions and behaviors"[22]. Leadership is the art and ability to influence and guide subordinates so that from the led party arises the will, trust, respect and obedience required in the use of tasks carried out to him, using tools and time but contains compatibility between group goals or unity with individual needs or goals[21].

Leaders as creatures of God who have different characters can determine their own path. The organization it leads can be carried out in various types or forms expressed by some opinions of experts as follows:

1) Bureaucratic Leadership Style; This bureaucratic leadership style is illustrated by the statement "Lead based on rules". Lead behavior is characterized by the tightness of the implementation of a procedure that has been applicable to the leader and his men. Bureaucratic leaders will generally make all decisions based on the rules that have been in force and there is no longer flexibility. All activities must be centered on the leader and a little freedom to others in creating and acting, even then must not break away from the provisions that have been applied. As for some characteristics of bureaucratic leadership style is that the Leader will determine all decisions related to the entire work and will order all subordinates to be able to carry it out; The leader will determine all standards on how subordinates will perform the task; There is a very clear sanction if a subordinate cannot carry out duties in accordance with the standards of performance that have been determined[23].

2) Charismatic Leadership Style; The advantage of this charismatic leadership style is that it is able to attract people. They will be fascinated by the way he speaks that will excite. Usually leaders with this personality style will be visionary. They love change and challenges. Perhaps, the biggest weakness of this type of model leadership can be analogous to the proverb Blank Barrel that Loud sounds. They are only able to attract people to be able to come to them. After some time, the people who come will be disappointed because of inconsistency. What was said was not done. When asked for accountability, the leader will always give excuses, apologies, and promises.

3) Analytical leadership style; In this type of leadership style, usually decision making is based on a process of analysis, especially logical analysis of any information obtained. It will be results-oriented and will place more emphasis on detailed and long-term dimensions. Leadership of this model prioritizes logic by using several reasonable and quantitative approaches.

4) Visionary Leadership Style: Visionary leadership is a pattern of leadership aimed at being able to give 
meaning to work and business that needs to be carried out jointly by company members by providing direction and meaning to a work and effort done based on a clear vision[23].

Sutomo Himself in addition to being one of the central figures in the battle of Surabaya, in the battle against the Dutch and their allies there is something that can be exemplated, namely about his leadership in leading the battle. When in a desperate state Sutomo appealed that the youths from Surabaya should not leave the city. Also when Surabaya lacked artillery Sutomo called for Surabaya to be assisted by cannon firemen. Sutomo's call was welcomed by the highest headquarters of TKR Yogyakarta, who then sent Major General Suwardi along with 23 prospective artillery. Sutomo at all times galvanized and stimulated the revolutionary spirit organized into one giant fortress to face the Allies (Britain). Sutomo's fiery voice shrilled the enemy's guts we will not stop the fighting as long as the Belada (foreign army) soldiers are still on the Indonesian mainland. This voice indirectly weakens the spirit of the enemy who already feels anxious to face the fierce resistance of the Indonesian nation. Evidence of Sutomo leadership is not formed briefly, but through a long process. Among others, Sutomo has also been a leader in BPRI and Sutomo also succeeded as a leader through his propaganda he attracted the Indonesian Youth Force Organization Klinter Building (APIK) under the leadership of M.siffun to merge with the BPRI organization under the leadership of Sutomo.

\section{IV.CONCLUSION}

The Battle of November 10, 1945 in Surabaya was a major battle involving the people of Surabaya in large numbers with military forces trained in the second world war. This battle catapulted the name of a figure who was referred to as the leader of the resistance movement. Sutomo's leadership in the battle of November 10, 1945 in Surabaya is strongly tied to the movement of the people of Surabaya. Sutomo in his service to the nation, in his leadership has implemented strategic leadership, and has a bureaucratic leadership style, charismatic leadership style, analistic leadership style and visionary leadership style that is able to analyze a situation, attitude, and action is always based on a pattern of thinking critically and strategically to make a change that can create a better future for the nation. Sutomo strategic leadership can be used as an example for Indonesian citizens, especially for youth to model their strategic leadership, namely in terms of decision making needed to think critically and think analytically, in order to predict the future impact of the decisions taken. The results of research on The Strategic Leadership of Sutomo during the battle of November 10, 1945 in Surabaya still have shortcomings and need improvement. Therefore, it is expected that further and in-depth research and study will be needed to improve the history of the role of Sutomo in the battle of November 10, 1945 in Surabaya so that it can be used as a complete reference for better education and historical learning.

\section{REFERENCES}

[1] William H. Frederick \& Soerio Soeroto (Eds.), Pemahaman Sejarah Indonesia: Sebelum dan Sesudah Revolusi. Jakarta: LP3ES, 1982.

[2] B. Sumarto, Pertempuran 10 November 1945 Citra Kepahlawanan Bangsa Indonesia di Surabaya. Surabaya, 1986.

[3] H. W. Suhario Padmodiwiryo, Memoar Hario Kecik: autobiografi seorang mahasiswa prajurit. Yayasan Obor Indonesia, 1995.

[4] W. H. Frederick, Pandangan dan gejolak: masyarakat kota dan lahirnya Revolusi Indonesia (Surabaya 1926 - 1946). Jakarta: PT. Gramedia, 1989.

[5] A. DANI, "Kepemimpinan Gubernur Suryo Selama Pertempuran 10 November 1945 Di Surabaya," Avatara, vol. 5, no. 3, 2017.

[6] R. A. Endra Kusum, Syaiful Anwar, Helda Risman, "PERTEMPURAN SURABAYA TAHUN 1945 DALAM PERSPEKTIF PERANG SEMESTA,” J. Inov. Penelit., vol. 1, no. Vol 1 No 12: Mei 2021, p. 2832, 2021.

[7] Sugiyono, Metode Penelitian Kuantitatif, Kualitatif, dan R\&D. Bandung: CV. Alfabeta, 2017.

[8] Pusjarah Tentara Nasional Indonesia, Sejarah TNI Jilid I, 1st ed. Jakarta: PT. SIDISI, 2000.

[9] A. Mansyur, P. Widodo, and M. Iswanto, "Perjuangan Pemuda Surabaya Pada Pertempuran 10 November 1945 Dalam Upaya Meningkatkan Rasa Patriotisme dan Nasionalisme Rakyat Indonesia,” J. STKIP PGRI Sidoarjo, vol. 2, no. 2, pp. 1-13, 2017.

[10] Sutomo, Pertempuran 10 November 1945, Kesaksian \& Pengalaman Seorang Aktor Sejarah. Jakarta: Visimedia, 1951.

[11] Fery Taufiq, Pekik Takbir Bung Sutomo, Perjalanan Hidup, Kisah Cinta, dan Perjuangannya. Yogyakarta: Araska, 2020.

[12] D. A. Pratama and Sumarno, "Tindakan Bung tomo Dari Kejaran Pasukan Belanda Di Jawa Timur Dan Strategi Perjuangannya 19451949," AVATARA J. Pendidik. Sej., vol. 11, no. 2, pp. 1-10, 2021.

[13] Nugroho Notosusanto, Pertempuran Surabaya. Jakarta: Mutiara Sumber Widya, 1985.

[14] Roeslan Abdulgani, 100 Hari di Surabaya yang Menggemparkan Indonesia. Jakarta: Yayasan Idayu, 1974.

[15] Asmadi, Pelajar Pejuang. Jakarta: Sinar Harapan, 1995.

[16] Osman Raliby, Documenta Historica. Jakarta: Bulan Bintang, 1952.

[17] Sutomo, Bung Sutomo Menggugat. Jakarta: Visimedia, 2008.

[18] Zaenul Iskandar, "KEPEMIMPINAN STRATEGI 'Konsep dan Implementasi Kepemimpinan Islami,"” JUPE J. Pendidik. Mandala, vol. 4, p. 57, 2019.

[19] J. Suspurwanto, "KEPEMIMPINAN STRATEGIS JENDERAL SUDIRMAN DALAM PENGABDIANNYA SEBAGAI PRAJURIT TENTARA NASIONAL INDONESIA," J. Strateg. Pertahanan Semesta, vol. 6 Nomer 1, 2020.

[20] A. Chaniago, "Pemimpin dan kepemimpinan," Pemimpin Dan Kepemimp., vol. 10, no. 9, p. 16, 2017.

[21] W. N. Aidil Hajri, I Wayan Midhio, "Cavalry battalion/badak ceta cakti in cijantung jakarta)," pp. 33-60, 2018.

[22] Hadari Nawawi, Administrasi Pendidikan. Jakarta: CV Haji Masagung, 1987.

[23] B. Mattayang, "Jemma | Jurnal of Economic ," Jemma J. Econ. Manag. Account., vol. 2, no. 4, pp. 45-52, 2019. 